\title{
Scottish tourism: Scenarios and vision
}

\author{
Ian Yeoman \\ Received (in revised form): 26th May, 2004
}

VisitScotland, 23 Ravelston Terrace, Edinburgh EH4 3TP, UK. Author Query??Need tel/fax/e-mail

\begin{abstract}
Ian Yeoman is the scenario planner for VisitScotland, the national tourism agency of Scotland. lan is also the editor of the Journal of Revenue and Pricing Management and author/editor of nine books about the tourism industry. lan has a PhD in management science from Napier University, Edinburgh.
\end{abstract}

Peter Lederer is chairman of VisitScotland and managing director of Gleneagles. He is committed to improving quality, educational standards and training opportunities within the hospitality and tourism industries. Peter is an honorary professor at the University of Dundee and was awarded an honorary DBA by Queen Margaret University College, Edinburgh. In addition, Peter is a Master Innholder and Freeman of the City of London, as well as a Liveryman of the Worshipful Company of Innholders.

\section{ABSTRACT}

KEYWORDS: tourism, Scotland, VisitScotland, scenario planning, vision, national tourism organisation

In order to understand the potential for tourism in Scotland, it is important to look beyond the near future. Four scenarios have been created that paint contrasting pictures of the future. The 'Dynamic' scenario creates a $\mathcal{E} 10 b n$ tourism economy with tourism being the number-one industry in Scotland. The 'Weekend Getaway' sees tourism based upon consumerism and play. The value of tourism in this scenario is E7.6bn. 'Yesterday's Destination' means tourism is based upon the past, and the industry is found to be too complacent. An uncompetitve industry means that growth is only 1 per cent per annum and valued at £5.1bn.
Finally, 'Exclusive Scotland' means that the Scottish economy has failed as deflation has taken the soul out of the country but favourable exchange rates mean that international high-spending tourists flock to exclusive resorts. Tourism in this scenario is a $\mathrm{f}^{2.6 b n}$ industry. These four scenarios follow different paths and are driven by different circumstances. But within all of the scenarios, tourism exists. The opportunity for Scotland is to maximise its potential in order that tourism is Scotland's first and everlasting industry.

The paper begins with a commentary by Peter Lederer.

\section{COMMENTARY BY PETER LEDERER}

Post-devolution, Scotland has a unique opportunity to think and act differently; a unique opportunity to shed some of the past 'baggage' and start building a confident, successful country competing with the best in the world. Tourism can and must play a major role in the economic and social success of this new Scotland. Tourism must be a significant, growing part of a smart, successful strategy for Scotland.

Tourism continues as one of the fastestgrowing industries in the world and currently contributes $\mathcal{E}^{4} .5 \mathrm{bn}$ to the Scottish economy. But we are at an important crossroads. We have the essential physical ingredients of a successful tourism destination, but to compete in the 21 st century we will need ambition, strong leadership, commitment and passion.

After a fundamental reorganisation and renewed strategic focus, VisitScotland aims to develop a strong brand for Scottish tourism, develop successful marketing strategies,
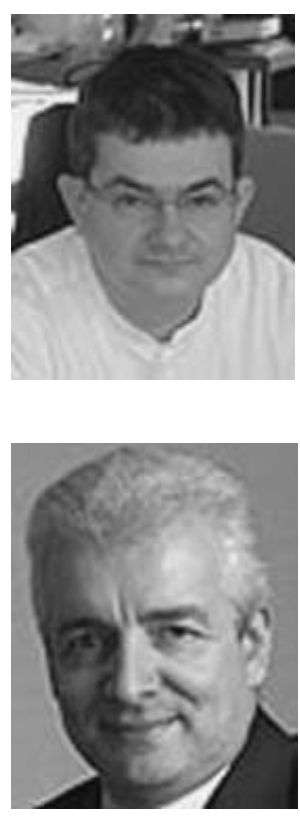

Journal of Vacation Marketing Vol. 11 No. 1, 2005, pp. 67-83, (c) SAGE Publications London, Thousand Oaks, CA and New Delhi.

www.sagepublications.com DOI: 10.1177/1356766705050844 
deliver more direct access to Scotland, develop e-business opportunities to the full and work collaboratively with key stakeholders in the public and private sectors.

To deliver these objectives it is very important that there is a constructive, intelligent and strategic debate which will help develop the vision - what do we want the Scottish tourism industry to look like in 2015? This paper is the result of a great deal of thought and expertise and I look forward to taking the debate forward.

\section{INTRODUCTION}

The worldwide growth of tourism must count as one of the most remarkable achievements of the last 50 years. ${ }^{1}$ With one or two exceptions, the proportion of the world population taking part in tourism activities has risen year on year over the last three decades. The tourism industry in the UK has prospered for the last 20 years. Almost every year, a greater proportion of UK residents takes part in tourism-related activities, whether domestic or international. This propensity for tourism is linked to affluence and general well-being. Growing disposable income and a desire for a better quality of life have produced new tourists as their aspiration grows beyond traditional holidays. They now have a propensity for faraway places and weekend breaks. The more affluent people become the more is spent on leisure. Spending on out-of-home leisure has nearly doubled over the last decade and now comprises 25 per cent of total household expenditure. $^{2}$ The importance of tourism cannot be overstated. According to the World Tourism Organisation, ${ }^{3}$ tourism is the world's largest growth industry. Receipts from international tourism have increased by an average of 3.2 per cent per annum since 1995 , to reach US\$474bn in 2002. During the same period, international arrivals rose by a yearly average of 2.7 per cent to reach 703 million in 2002.

But this enthusiasm is compounded by an uncertain economic future and the exposure of tourism to a series of shocks in the world, such as 11 th September, ${ }^{4}$ SARS,${ }^{5}$ war in
Iraq $^{6}$ and Hurricane Michelle. ${ }^{7}$ Tourism and aviation seem to be the front-line industries that are exposed to these shocks. Combined with other known trends of consumer behaviour, ${ }^{8}$ climate change ${ }^{9}$ and demographic change $^{10}$ which will impact on tourism, there is a feeling that the tourism industry is at a crossroads.

Tourism in Scotland is now a $\mathcal{L}^{4} .5 \mathrm{bn}$ industry -5 per cent of Scotland's GDP and accounts for 8 per cent of employment. ${ }^{11}$ Tourism has flourished in Scotland since Victorian times ${ }^{12}$ and has the potential to be the key pillar, if not the bedrock, of the economy 100 years from now. One thing is certain: tourism will be here in 2015 . It is an industry which cannot be outsourced to India or Hungary, as are financial services and call centres. It is an industry which will last longer than oil and gas, when these resources are exhausted. More importantly, it is an industry which represents the nation's identity, values and culture. Tourism is synonymous with Scotland - they are inseparable.

In order to understand the potential for tourism in Scotland, it is important to look beyond the short-term future. Plans for the immediate horizon are in place and embodied in the 'Tourism Framework for

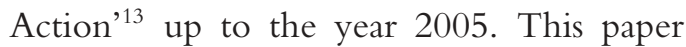
looks beyond that, to around 2015, and portrays four plausible futures for Scottish tourism, from demise to growth, concluding with a vision of VisitScotland's aspiration. Which future materialises will largely depend on how well prepared the industry and the country are to rise to the challenges ahead.

\section{SCOTTISH TOURISM: OPPORTUNITIES AND THREATS}

A Scottish parliamentary report ${ }^{14}$ implied that Scottish tourism was at a turning point. Embryonic themes have emerged stating that Scotland must look to the future and be prepared. What one sees in the near future is a range of opportunities and threats that will influence the future of Scottish tourism. 


\section{Opportunities}

- Fantastic landscape, well suited for outdoor activities and adventure tourism. ${ }^{15}$

- A country that is rich in culture, exemplified by the Edinburgh International Festival ${ }^{16}$ and Hogmanay.

- Vibrant cities: ${ }^{17}$ Edinburgh is the UK's number-two weekend-break city destination, followed by Glasgow (fifth) and Inverness (11th).

- World-class business tourism facilities, positioning Scotland as a leading meetings, incentives, conference and exhibitions ${ }^{18}$ destination.

- Accessible diversity: an incredible variety of landscapes and experiences in a small area. ${ }^{19}$

- A large domestic (UK) tourism market to draw on, which tends to be more robust in times of shock (ie 11th September, war in Iraq).${ }^{20}$

- Several airports with internal UK and an increasing number of direct short-haul European flights. ${ }^{21}$

- Many of Scotland's key products fit with consumer trends in lifestyles and demand for holiday experiences. ${ }^{22}$

- Growth in eco-tourism. ${ }^{23}$

- A safe destination in times of increasing concern with security. ${ }^{24}$

- Uniqueness as typified by traditional and contemporary icons. ${ }^{25}$

- An ageing population which has more disposable income and ability to travel off-season. The 50-64 age group spends more per household on holidays than any other. ${ }^{26}$

- Ahead of the competition in developing e-commerce, which enables the visitor to design bespoke holidays. ${ }^{27}$

- Historical connections and Scottish diaspora. $^{28}$

- High media profile through film industry. $^{29}$

- Oasis of relaxation in an increasingly stressful world. ${ }^{30}$

\section{Threats}

- A voice of disunity that spends its time blaming each other. ${ }^{31}$ A scenario in which the country takes the low road and becomes isolated. This isolation is driven by the attitudes of parochialism and protectionism. ${ }^{32}$

- The country has a tendency to put down what it has achieved. ${ }^{33}$ Scotland is the envy of other destinations. Scotland has a rich history and a natural product, as well as modern experiences of festivals, ${ }^{34}$ fun and enjoyment.

- Although Scotland has invested in a transport structure, this has not been done quickly enough nor of the right quality. One only has to look at other destinations to see what they have achieved by comparison. ${ }^{35}$

- In a scenario of continued growth, there is now a major constraining factor in terms of skilled labour shortages. For example, Glasgow has recently highlighted 1,000 job vacancies in tourism and hospitality. ${ }^{36}$

- Changes in demographics mean the population is getting older. An older population means increased health costs and less innovation. ${ }^{37}$

- There is a lack of family holiday centres compared with other destinations.

- The threat of economic downturn puts the brakes on consumer spending in the immediate horizon. This downturn is accelerated by less disposable income, higher saving ratios, pension worries, lack of confidence and a world of uncertainty, leading to a general feeling of financial insecurity. ${ }^{38}$

- There is a risk of a deflation economy, where the prices never go up but will always go down. ${ }^{39}$ In this economic situation Scotland is perceived as a highcost destination in terms of service and product. The manufacturing industry is forced to relocate to low-cost destinations. Even industries that are based upon 'information provision' relocate to the Asian economies.

- A world of risk and concern for safety which brings disruption to tourism and aviation, ${ }^{40}$ ie 11 th September and Iraq.

- Changes in climate that result in warmer summers and winters, accompanied by 
more rain. An increase in levels of rainfall will impact upon Scotland's outdoor activities, making people think twice about heading north. A weather cycle that is more disruptive will spell the end of skiing and snowsports in Scotland. ${ }^{41}$

- The country is unable to take seriously, through legislation, the importance of environmental sustainability and managing growth for future generations. ${ }^{42}$

- If Scotland fails to act, tourism could, like heavy manufacturing before it, ${ }^{43}$ become a relic of Scotland's economic past rather than a vibrant industry making a significant contribution to the prosperity of the country.

\section{SCENARIO PLANNING METHODOLOGY}

A scenario planning process has been used in order to create a range of alternative plausible futures and to stimulate a strategic conversation $^{44}$ about the future of Scottish tourism. Scenario planning is a process of painting pictures rather than a forecast of the future, a process in which possible worlds could unfold which are unimaginable, unthinkable and unpredictable. ${ }^{45}$ But scenarios represent futures which are plausible, based upon trends and a range of assumptions about the future. The principles and history of scenario planning are well documented as a means of developing strategic futures at Shell International. ${ }^{46}$ Shell's interest in scenarios arose from the increasing failures of planning based upon forecasts in the mid1960s. Scenarios were initially developed as a way to plan without having to predict things which everyone knew were - strictly speaking - unpredictable.

\section{FOUR PLAUSIBLE FUTURES}

Figure 1 represents a scenario matrix which frames four plausible futures for Scottish tourism around 2015. The matrix is built on two themes, economic environment and consumer propensity, with alternative out-

Figure 1 Scotland 2015

\section{Creating the four scenarios}

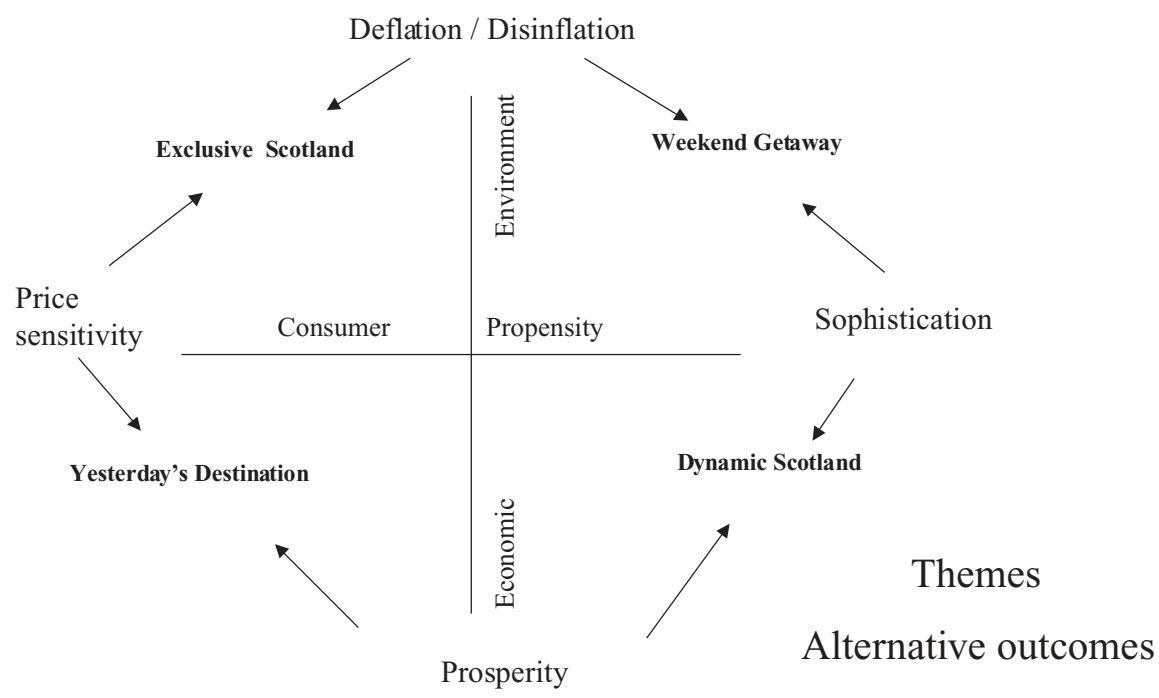

Scenarios 
comes. The themes were constructed from a range of drivers which shape tourism, including exchange rates, GDP, governance, health, fiscal policy, safety, disposable income, price sensitivity/yield, transport, science, perceptual values, media, environment, demographics, history and leisure activities. The outcomes represent alternatives rather than opposites. For the economic environment, outcomes are identified as deflation/disinflation or prosperity; for consumer propensity outcomes are identified as price sensitivity or sophistication.

These alternative outcomes become the framework for four possible future tourism scenarios. They are named as Weekend Getaway, Dynamic Scotland, Yesterday's Destination and Exclusive Scotland. These scenarios paint a picture of the size and shape of tourism in 2015: they do not represent the policy of VisitScotland, but rather a construction by the author in which readers can think about the future. Scenarios represent plausible futures, not exact futures. This paper represents only the tip of the iceberg of the scenarios, as a wealth of secondary research and interviews represent the mass of the scenarios.

\section{Scenario 1 - Dynamic Scotland}

Scotland is a dynamic country which accepts a diversity of views. A contemporary culture drives tourism. Tourism is Scotland's number-one industry in terms of employment, recognition and GDP. Prosperity is fuelled by favourable exchange rates, lower income tax, a concern for the environment, less duty on fuel and investment in infrastructure. Scotland is an international destination with clearly segmented activities, such as festivals, culture, golf, conventions and well-being, targeting top-end $\mathrm{AB}$ socio-economic groups, young families and business tourists.

The key points of this scenario are:

- high disposable income

— favourable exchange rates

- leading international tourism destination

- growth from business and holiday tourism
- Scotland is a tourism economy

- 7 per cent growth in tourism expenditure.

Tourism is now a $10 \mathrm{bn}$ industry which has grown at a rate of 7 per cent per annum since 2003 (Figure 2 and Table 1). The industry directly employs 350,000 people, making it Scotland's number-one industry in terms of employment and GDP. In the early part of the century, Scotland was losing its market share of international tourists. But all that changed around 2010, when international tourists wanted to come to Scotland for both holidays and business tourism. Tourism is now the chief revenue generator of the Scottish economy and Scotland is a leading international destination. The industry is embedded in everyday life.

It was the re-establishment of Scotland as an international tourism destination which made all the difference. Tourism in Scotland had for too long placed too much emphasis on domestic tourism, but with very favourable exchange rates, a first-class product and a desirable image international tourists have flocked back, coming from both East and West. The American market, which traditionally had a high affinity with Scotland, grew even stronger. A realisation came across the world that everything Scottish and Celtic had cultural capital and acclaim - whether it was Sir Walter Scott's 'Lady of the Lake' or Billy Connolly's banter. VisitScotland's 110 per cent Scotland programme was important in uniting the partners and players in talking up a tourism economy in order to create and action change. The importance of tourism is now recognised in every sector of the Scottish economy (Table 2), to the extent that every single person in Scotland now knows that the nation's prosperity is due to tourism.

The most important trend of well-being has facilitated Scotland's climb in the World Tourism Organisation's league tables. Whereas in 2003 New Zealand was held up as the benchmark, now the tide has turned and Scotland is widely recognised as having the most efficient and welcoming tourism industry in the world. VisitScotland is now a 


\section{Dynamic Scotland scenario 2015 Revenue projection $(£ \mathrm{~m})$}

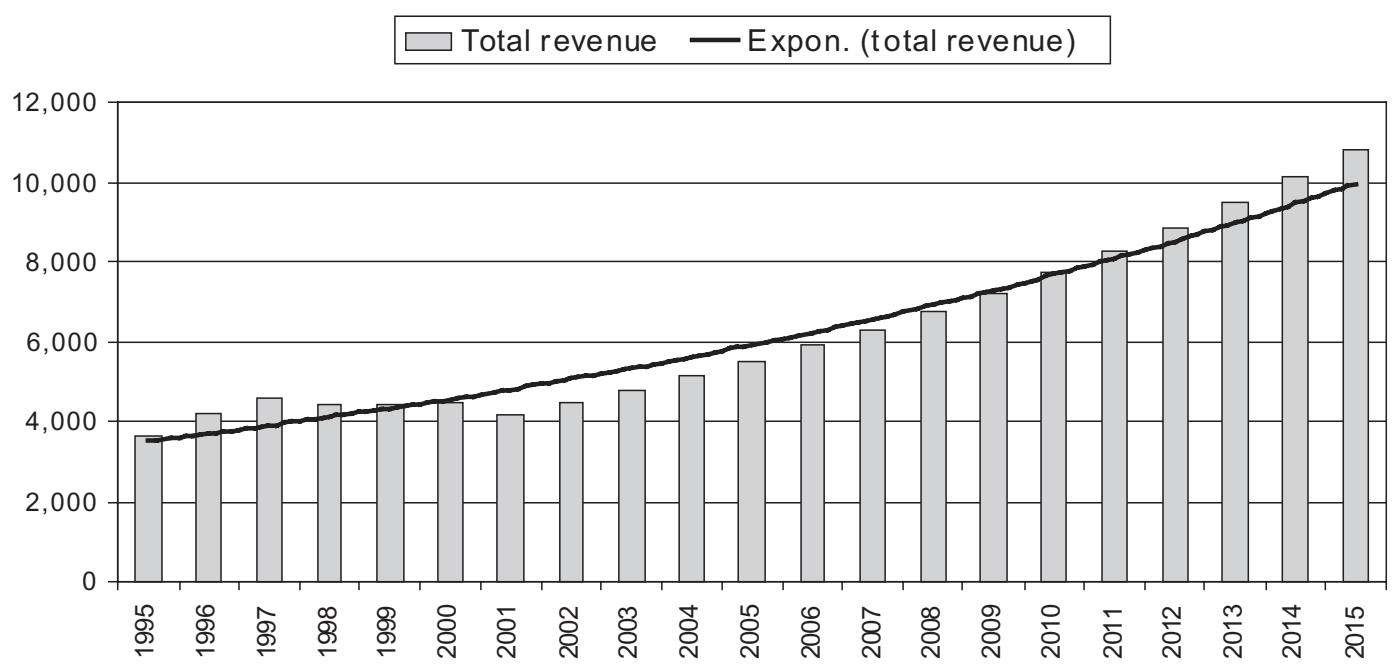

Table 1: Dynamic Scotland - The value of vourism in 2015

\begin{tabular}{lrrrrrr}
\hline Expenditure Type & $\begin{array}{l}\text { UK tourism } \\
\left(\mathcal{L}_{\mathrm{m}}\right)\end{array}$ & $\%$ & $\begin{array}{l}\text { Overseas } \\
\text { tourism }(£ m)\end{array}$ & \multicolumn{1}{c}{$\%$} & \multicolumn{1}{c}{ Total } & $\%$ \\
\hline Holidays & 5,197 & 69 & 1,625 & 50 & 6,825 & 63 \\
Business & 1,590 & 21 & 975 & 30 & 2,565 & 24 \\
Visiting friends and relatives & 680 & 9 & 400 & 12 & 1,080 & 10 \\
Other & 110 & 1 & 250 & 8 & 360 & 3 \\
Total & 7,577 & 100 & 3,250 & 100 & 10,827 & 100 \\
\hline
\end{tabular}

Table 2: Dynamic Scotland spending patterns

\begin{tabular}{lrr}
\hline Spend & \multicolumn{1}{c}{ fm } & $\%$ \\
\hline Leisure Spending & 3,115 & 29 \\
Eating \& Drinking & 2,185 & 20 \\
Travel & 2,135 & 20 \\
Accommodation & 2,210 & 20 \\
Other & 1,182 & 1 \\
Total & 10,827 & $100 \%$ \\
\hline
\end{tabular}

public/private sector partnership, with the tourism industry driving strategy and marketing activity. VisitScotland is now benchmarked as being the best tourism agency in the world. It is envisaged that VisitScotland will be a wholly private company in 2020 , because it is seen that the state no longer needs to intervene in tourism as the industry is strong, focused and successful.

A Dynamic Scotland means that Scotland welcomes visitors from all walks of life and 
different socio-economic groups. Scotland is accessible to all, both physically and emotionally. It caters for a diversity of experiences and cultures. For example, HQ Scotland has fuelled massive growth in business tourism; whereas touring holidays are based upon high-yield $\mathrm{AB}$ tourists with lots of disposable income.

Scotland's product portfolio is grouped into the following: playful Scotland; contemporary Scotland; body, mind and spirit; business tourism, city breaks; and touring and exploration. Each product integrates with VisitScotland's quality assurance scheme, which is like a club, is self-regulated and which all tourism providers want to join. The 'club' focuses on customer service and improvement - a sort of total-qualitymanagement approach.

\section{Scenario 2 - Weekend Getaway}

Scotland is positioned as the weekend getaway, in which tourism is based upon consumerism and play. It is a short-break and European destination. Scotland offers a diversity of products and experiences which cater for a broad spectrum of visitors. The Weekend Getaway is very much about disposable income and competing demands for consumers' leisure time. Falling air fares and hotel prices make it so much easier to get here, and so affordable, that a weekend away almost becomes an impulse purchase. But the weekender is not an easy option, as many other destinations offer similar products and experiences.

The key points of this scenario are:

— direct access

- strong competition for disposable income

- favourable exchange rates which attract European visitors

- lots of competition from other destinations

- transport is a key driver

- quality is a hygiene factor

- growth from holiday rather than business tourism

- attractive leisure destination

- 4 per cent growth per annum.
Tourism is now a $f 7.6 \mathrm{bn}$ industry which has grown at a steady pace of 4.4 per cent per annum since 2003 (Figure 3). The UK domestic market is worth $65.8 \mathrm{bn}$, whereas overseas tourism is worth $f 1.7 \mathrm{bn}$. Tourism employs 250,000 people, making it Scotland's number-one employer in the private sector. The growth in the domestic market has been driven by the improvements in transport infrastructure, which means that tourists leave their office at $5 \mathrm{pm}$ on a Friday evening and are in Scotland by $8 \mathrm{pm}$. There has been substantial growth come from the south-east of England, based upon Scotland being an emotionally appealing, accessible destination. More budget carriers and continued investment in rail infrastructure have allowed Scotland to become a leading weekend destination. In fact, Scotland is no longer perceived as a tourism destination, rather as a provider of leisure services and goods.

It is understood the 'weekender' market is about 'disposable income' and 'leisure spend', and it is this which is driving growth. Scotland is a destination which some commentators have described as hedonistic, in which consumers are pleasure-seeking, middle-class people who want to indulge themselves.

Competition is not perceived as being other destinations but rather DIY activity, white goods and various forms of entertainment. Targeting the 'weekender' is not an easy option, as visitors are in an environment of disinflation which means that yields on accommodation and travel are always falling, but spending on retail and activities is rising (Table 4).

Scotland's accessibility has resulted in a focus on European markets rather than longhaul visitors. Favourable exchange rates and contemporary cities mean that Scotland is more competitive and desirable than destinations such as Paris, Warsaw, Rome and Madrid. There is a tartan renaissance, in which many Europeans as far afield as Poland in the east and Iceland in the north have identified with Scotland's enduring proposition of play, freedom, romance and creativity. There is a strong product portfolio: adventure, play and sport; arts, music and 


\section{Weekend Getaway scenario 2015 Revenue projection $(£ \mathrm{~m})$}

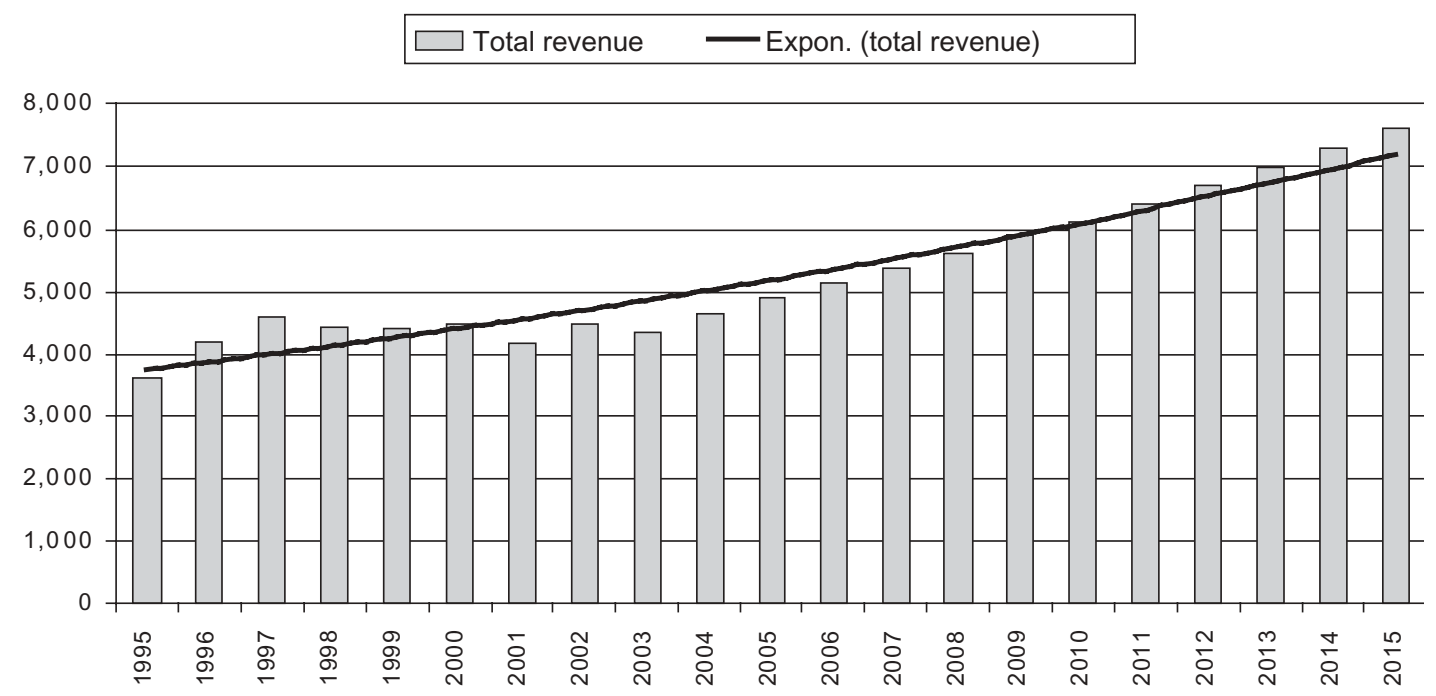

Table 3: Weekend Getaway — The value of tourism in 2015

\begin{tabular}{lrrrrrr}
\hline Expenditure Type & $\begin{array}{l}\text { UK tourism } \\
(\text { (m) }\end{array}$ & $\%$ & $\begin{array}{l}\text { Overseas } \\
\text { tourism }(\AA m)\end{array}$ & $\%$ & Total & $\%$ \\
\hline Holidays & 40,70 & 70 & 875 & 50 & 4,946 & 65 \\
Business & 1,050 & 18 & 350 & 20 & 1,400 & 18 \\
Visiting friends and relatives & 645 & 11 & 455 & 26 & 1,100 & 14 \\
Other & 90 & 2 & 70 & 4 & 160 & 2 \\
Total & 5,855 & 100 & 1,750 & 100 & 7,605 & 100 \\
\hline
\end{tabular}

Table 4: Weekend Getaway Scotland spending patterns

\begin{tabular}{lrr}
\hline Spend & fm & \multicolumn{1}{c}{$\%$} \\
\hline Leisure spending & 2,375 & $31 \%$ \\
Eating and drinking & 1,550 & $20 \%$ \\
Travel & 1,405 & $18 \%$ \\
Accommodation & 1,420 & $19 \%$ \\
Other & 855 & $11 \%$ \\
Total & 7,605 & $100 \%$ \\
\hline
\end{tabular}

renaissance; body, mind and spirit; conventions; leisure retail cities; and rural and Gaelic Scotland.

By 2015, Scotland had realised that the growth in business tourism was not going to materialise. Companies were spending less on travel year on year, and videoconferencing technology came of age in 2012. But continued capital investment in exhibition space and the perception of Scotland as a safe and accessible destination meant that growth 
came from associations and conventions rather than from business-to-business transactions.

Tourism was perceived as the soaring eagle of the Scottish economy, a sector that grew steadily when other industries such as manufacturing, electronics and fishing were in decline. Those early sceptics and doomsday merchants who said the 'product lacks quality', 'the destination is too expensive' and 'service is poor' were all proved wrong. A determination to soar above the problem like an eagle, in order that the products, branding, quality and marketing were right, ensured that Scottish tourism grew at 4.4 per cent per annum when other destinations showed slower growth or decline.

In a competitive environment in which consumers have plenty of choice, Scotland realised that a programme of continuous investment was necessary in order to grow the industry continually. Initiatives included the following.

- A fitness-to-practise quality assurance programme, in which all tourism business were required to show competencies in order to gain a licence to operate. The programme had two parts: a compulsory certificate which covered all legal requirements such as health and safety, customer care, hygiene and training; and the diploma stage which encompassed more advanced subjects such as revenue management and innovation. The fitness-to-practise programme was an important development, as quality was seen by the consumer as a 'hygiene factor' rather than a 'distinguishing factor', because every destination had invested in quality. Such a programme ensured that businesses which were competitive survived, and those that were not simply died. The assurance element of the programme ensured a 100 per cent guarantee to the consumer or your money back if not completely satisfied.

- The Schmenner project (named after Professor Roger Schmenner, whose 'challenges for service managers' idea allowed product designers to find solutions for problems based upon the degree of customisation, interaction and labour intensity ${ }^{47}$ ) grasped the problem of demographic change and its implications for tourism. This initiative was different from others; instead of beating the same old drum about the lack of people entering the industry' or 'more training is required', the tourism innovation group set about designing products and creative solutions to the problem. New products and gadgets were designed which overcame the problem of labour supply. The Munro satellite-positioning watch (MSPW) enabled walkers to climb mountains without the need of a guide or map. The watch was popular with semi-experienced walkers because in popular resorts such as Glencoe there was always a shortage of experienced guides. Other projects focused on personal services, in which, for example, butlers were trained in neuro-linguistic programming. Even King William sent his butler on the course. Scotland's Butler Corps was the best-trained and most respected force in the tourism world.

Between 2004 and 2010 there were a number of developments and changes in tourism products and markets. For example, the accommodation sector polarised between two markets: first of all, accommodation providers in suburbia found that consumers wanted basic, safe and comfortable accommodation without all the frills. The budget accommodation sector thrived as the hotel bedroom became the 'spare guest bed' for urban populations spurred on by growth in visiting friends and relatives and the need for budget or value-for-money accommodation. Even in traditional holiday destinations visitors were spurning serviced accommodation for self-catering flats. Accommodation in these markets, like many other products in a disinflation economy, was now a commodity. But providers whose accommodation had a five-star status or was of a boutique style grew their businesses because consumers with high disposable incomes still wanted to be pampered. It was the providers 
whose businesses were perceived as, say, a traditional three-star hotel, or who were in a seasonal location, who were squeezed between rising costs and falling yields.

\section{Scenario 3 - Yesterday's Destination}

Scottish tourism is based upon the past, a world of icons and complacency. Scotland dreams of glory and the past. The problem is, the past is not quite good enough. Tourism is still here. But unfavourable exchange rates make Scotland an uncompetitive and second-division destination.

The key points of this scenario are:

- unfavourable exchange rates and outbound tourism

- decline in international tourism

- uncompetitive and expensive destination

- substantial decline in the short-break market
- second-division destination

-1 per cent growth per annum.

Scottish tourism is a $\$ 5.1 \mathrm{bn}$ industry which has grown at a rate of 1 per cent per annum since 2003 (Figure 4). The tourism industry directly employs 180,000 people and represents 4 per cent of GDP, which makes it still one of Scotland's important industries, but in slow decline. It is the "old dog' of the economy, as its value and contribution diminish in real terms. Scotland is a second-division destination which is struggling and uncompetitive.

Scotland's product portfolio concentrates on resorts and conventions; arts, culture and renaissance; senior tourism and health; and sport and activities. The market is very clear: it is associated with domestic tourism and traditional experiences. Visitors are segmented as 'grey and mature' or 'with young

\section{Yesterday's Destination scenario 2015 Revenue projection (£m)}

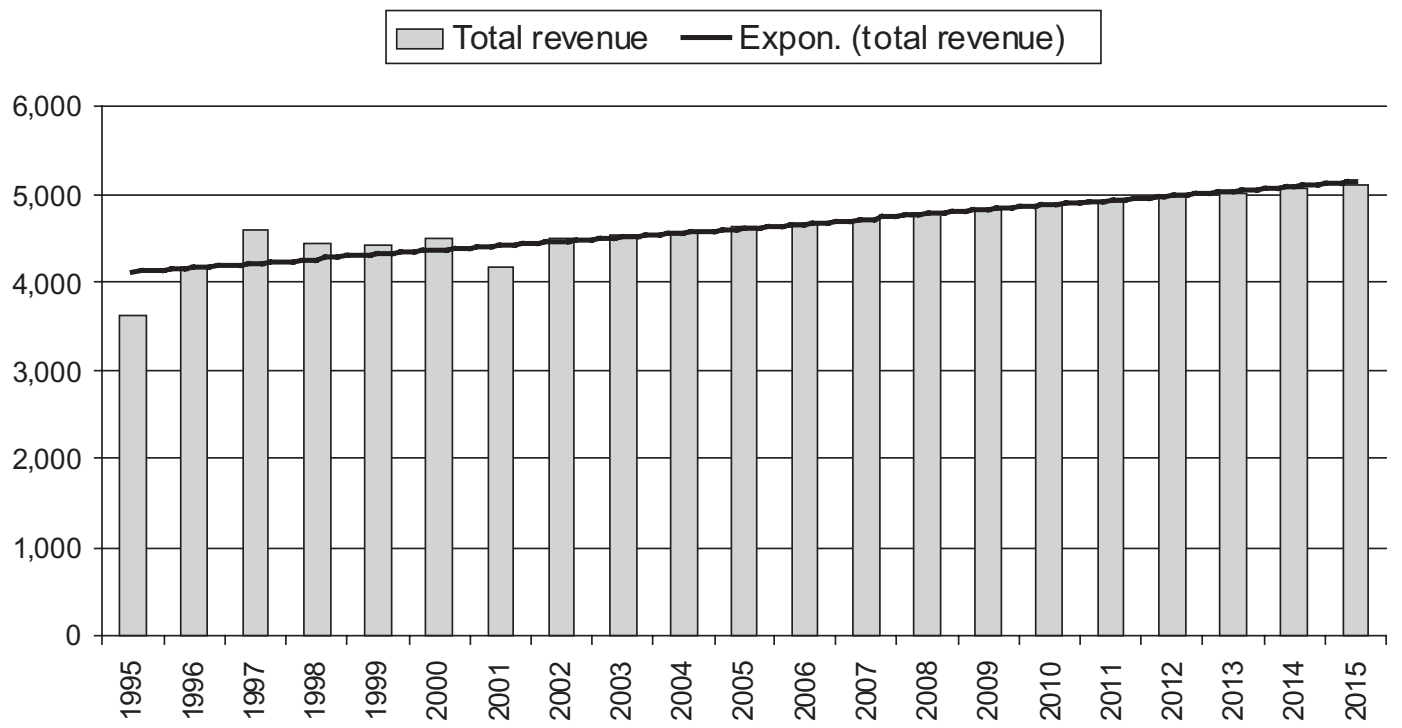


families' (Scotland is still a safe destination). Health tourism and small family centres have been the success stories of Scottish tourism, but these successes could not make up for the decline in the short-break market as a result of the increase in outbound tourism to international resorts. Business tourism, once the growing sector of Scottish tourism, is now in decline due to a lower volume of business travel, new technologies and a poor-quality business product (Table 5).

Unfavourable exchange rates mean that, although Scotland's economy is relatively strong and has invested in a decent infrastructure, people are not 'holidaying' in Scotland because the product, the price and the service just are not quite right. In an environment of price-sensitive consumers, value for money and destination image are important drivers. Scots can now get direct flights from Dundee to Prague for less than they could 20 years ago - but Czechs do not seem to want to come here! But plenty of Scots want to leave. Scotland remains a high-cost destination in a price-sensitive world. Although it is cheap to get there, the cost of accommodation and other products is too high.

The tourism industry introduced a compulsory 'quality-to-practise' scheme in 2009. This scheme focused on the product and the industry, and was well-meaning, but it actually added to the industry's costs and stifled innovation. VisitScotland, which was responsible for the scheme, was always viewed by the industry as the policeman.

As the population has aged, there is still some demand for nostalgia for the past. The bread-and-butter of Scottish tourism is still haggis, bagpipes and tartan. Tourism still makes a significant, if declining, contribution to the Scottish economy, but it is not seen as a driver of economic growth. In mid-summer the high streets of Pitlochry and St Andrews are still crowded with tourists but those tourists are spending less, every year there are fewer of them and for how much longer will they keep returning?

\section{Scenario 4 - Exclusive Scotland}

Scotland's economy has failed as deflation has taken the soul out of the country. The lack of disposable income, high costs, high unemployment and price-sensitive consumers have resulted in the collapse of domestic tourism. But international tourism is an important source of foreign exchange for the economy as resorts cater for the wealthy, discerning and exclusive tourist.

The key points of this scenario are:

- UK economy collapses: no disposable income

- weak domestic tourism

— favourable exchange rates

- international luxury and exclusive resorts

- 4 per cent decline per annum.

Tourism in Scotland is a $\mathcal{E}^{2}$.6bn industry, which has shrunk at a rate of 4 per cent per annum since 2003, mainly as a result of the collapse of the UK economy (Figure 5). Domestic tourism now contributes only E1.58bn: visitors just do not have the disposable income to spend on tourism, compounded by the fact that consumers have not, in any case, got the confidence to spend any money at all. Tourism is now a spatial

Table 5: Yesterday's Destination - The value of tourism in 2015

\begin{tabular}{lcrrrrr}
\hline Expenditure type & $\begin{array}{l}\text { UK tourism } \\
(\mathrm{f} m)\end{array}$ & $\%$ & $\begin{array}{l}\text { Overseas } \\
\text { tourism }(\mathrm{f})\end{array}$ & $\%$ & Total & $\%$ \\
\hline Holidays & 2,878 & 66 & 430 & 56 & 3,309 & 65 \\
Business & 740 & 17 & 115 & 15 & 855 & 17 \\
Visiting friends and relatives & 650 & 15 & 155 & 20 & 805 & 16 \\
Other & 75 & 2 & 70 & 9 & 145 & 3 \\
Total & 4,343 & 100 & 770 & 100 & 5,113 & 100 \\
\hline
\end{tabular}


Table 6: Yesterday's Destination spending patterns

\begin{tabular}{|c|c|c|}
\hline Spend & $f m$ & $\%$ \\
\hline Leisure Spending & 1,240 & 24 \\
\hline Eating and drinking & 1,150 & 22 \\
\hline Travel & 1,075 & 21 \\
\hline Accommodation & 1,060 & 21 \\
\hline Other & 588 & 12 \\
\hline Total & 5,113 & 100 \\
\hline
\end{tabular}

product which only extends to exclusive resorts rather than to the whole economy. Tourism, once described as everyone's business, is no longer like that.

Overseas visitors generate $\mathcal{E}_{1} 1.04 \mathrm{bn}$ and tourism is an important export for Scotland's failing economy. Visitors are centred on en- claves and all-inclusive luxury resorts. These 'gated' and 'exclusive' tourism resorts are owned mainly by international travel companies. Tourists tend to fly in and fly out of the destination without exploring Scotland. Consequently, the local population never see the tourists, as they tend to stay in their own secured compounds. These resorts are for those who can afford a divulgent lifestyle of pampering, from health spas to casinos to deer stalking.

The tourism industry employs 110,000 people, mainly in the hotel, restaurant and resort sectors. Domestic tourism revolves around the visiting friends and relatives (VFR) market and cheap-and-cheerful holidays. Scotland is a second-choice destination for the domestic tourist.

VisitScotland, the national tourism agency, has been reduced to a brochure and

Figure 5 Exclusive Scotland revenue projections

\section{Exclusive Scotland Scenario 2015 Revenue projection $(£ \mathrm{~m})$}

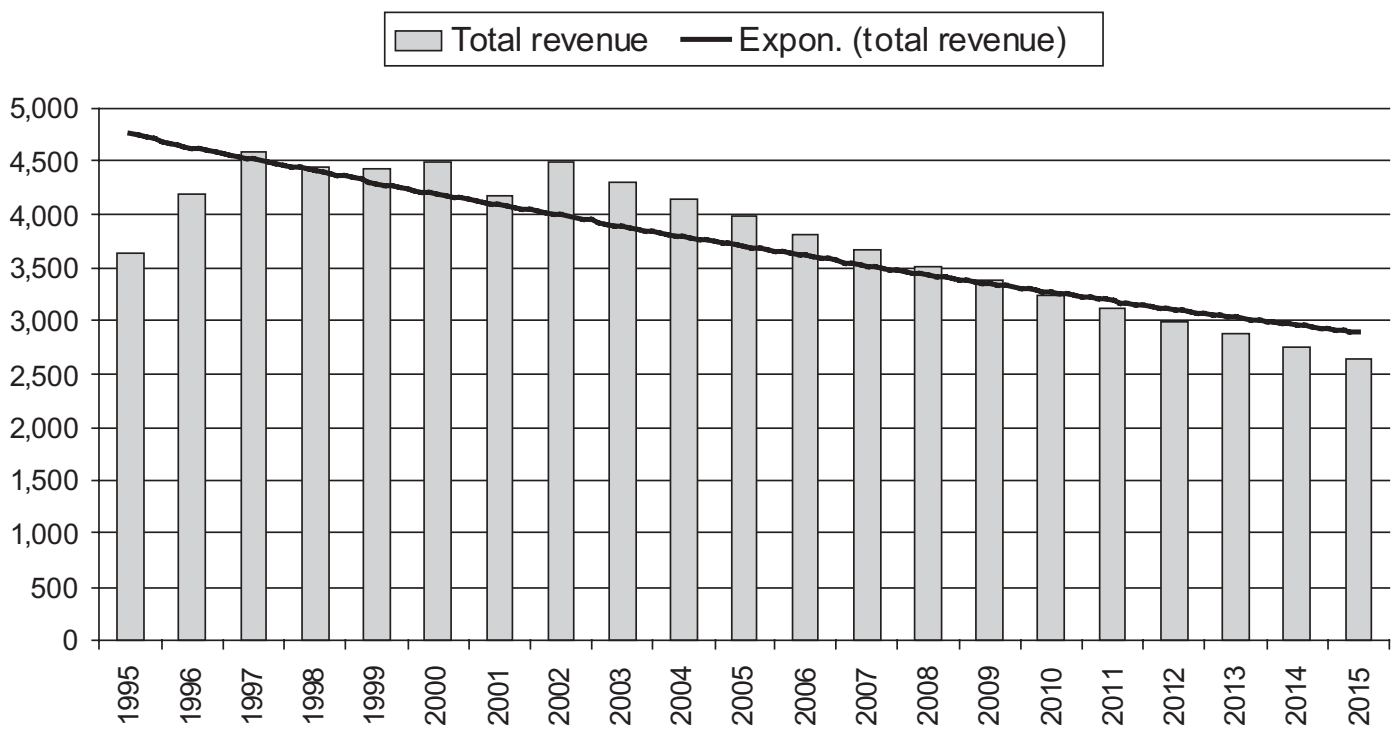


Table 7: Exclusive Scotland - The value of tourism in 2015

\begin{tabular}{lcrrrrr}
\hline Expenditure type & $\begin{array}{l}\text { UK tourism } \\
(\mathrm{E})\end{array}$ & $\%$ & $\begin{array}{l}\text { Overseas } \\
\text { tourism }(\mathrm{E})\end{array}$ & $\%$ & Total & $\%$ \\
\hline Holidays & 1,110 & 70 & 767 & 72 & 1,878 & 71 \\
Businesses & 275 & 17 & 80 & 8 & 355 & 13 \\
Visiting friends and relatives & 145 & 9 & 138 & 13 & 283 & 11 \\
Other & 53 & 3 & 75 & 7 & 128 & 5 \\
Total & 1,583 & 100 & 1,060 & 100 & 2,643 & 100 \\
\hline
\end{tabular}

internet provider within the UK market. Resources are now focused on the international market. Eighty per cent of tourism information centres (TICs) have been closed in the last ten years as the major resorts provide all the necessary information themselves. VisitScotland abandoned its progressive quality programme because of government cutbacks in non-essential services and, in any case, none of the providers wanted to join the scheme. What is left is a basic certification programme which covers the minimum safety standards. The luxury resorts tend to assess themselves. Tourism -

Table 8: Exclusive Scotland spending patterns

\begin{tabular}{lrr}
\hline Spend & \multicolumn{1}{c}{.m } & $\%$ \\
\hline Leisure spending & 845 & 32 \\
Eating and drinking & 480 & 18 \\
Travel & 510 & 19 \\
Accommodation & 525 & 20 \\
Other & 285 & 11 \\
Total & 2,643 & 100 \\
\hline
\end{tabular}

once accessible to all - is now accessible only to the few.

Little investment in the product has meant that Scotland has concentrated on the luxury end of the market, where the national agency, VisitScotland, promotes resorts and conventions, health and medicine and sport to overseas visitors. As tourism is an important export in a failing economy, a Tourism and Community Development Act in 2009 set out to maximise tourism's potential in order to generate jobs, involve local communities and create a tourism economy. The Act created a range of economic tourism zones, modelled on the Indian reservation, in which regions had tax incentives and special powers.

\section{CONCLUDING REMARKS - THE IMPORTANCE OF THE SCENARIOS}

Four scenarios have been presented which follow different paths and are driven by different circumstances (Table 9). Ultimately, the future should focus on Dynamic Scotland, a $\mathcal{E}_{10.8 \mathrm{bn}}$ tourism economy that is

Table 9: Scenario revenue projections

\begin{tabular}{|c|c|c|c|c|c|c|c|c|}
\hline & $\begin{array}{l}2015 \\
\text { Dynamic } \\
\text { Scotland }\end{array}$ & $\%$ & $\begin{array}{l}2015 \\
\text { Weekend } \\
\text { Getaway }\end{array}$ & $\%$ & $\begin{array}{l}2015 \\
\text { Yesterday's } \\
\text { Destination }\end{array}$ & $\%$ & $\begin{array}{l}2015 \\
\text { Exclusive } \\
\text { Scotland }\end{array}$ & $\%$ \\
\hline UK tourism $(£ \mathrm{~m})$ & 7,577 & 70 & 5,855 & 77 & 4,343 & 85 & 1,583 & 60 \\
\hline $\begin{array}{l}\text { International tourism } \\
\qquad(£, \mathrm{~m})\end{array}$ & 3,250 & 30 & 1,750 & 23 & 770 & 15 & 1,060 & 40 \\
\hline Total $(f, \mathrm{~m})$ & 10,827 & 100 & 7,605 & 100 & 5,113 & 100 & 2,643 & 100 \\
\hline $\begin{array}{l}\text { Growth (\% per } \\
\text { annum) }\end{array}$ & 7 & & 4.4 & & 1 & & -4 & \\
\hline
\end{tabular}


vibrant and dynamic. But such an ambitious scenario may not be attainable until after 2015, and the Weekend Getaway scenario may be the stepping stone to Dynamic Scotland. In both of these positive scenarios, tourism grows at a rate that is faster or equals the World Tourism Organisation's own prediction of 4.4 per cent per annum, thus making tourism a significant force in Scotland's economic landscape.

Demographic change is going to impact upon Scotland between 2025 and 2035, resulting in a nation where government expenditure may be driven by the cost of health and social services. Scotland could be the most economically inactive part of the UK by 2035 . This, compounded by the decline in manufacturing industries, the threat to financial services and a cost-driven economy, could result in a bleak picture for Scotland.

One way to address the problem before it really starts to bite is to create a tourism economy in which tourism acts as a contemporary catalyst where people want to live, work and holiday in Scotland. This means 'putting' and 'making' tourism Scotland's 'first and everlasting' industry. Such a bold move means capturing the spirit of the nation, realising its potential and taking the proposition seriously. If this is not done, Scotland will become Yesterday's Destination.

Without doubt tourism is the world's most important industry, with holidays being available at both the South and North Poles - and everywhere in between. With the expansion of the EU and the resultant ease of travel between and within countries and the improvements in transport, destinations such as Poland and Estonia will, in 2015, be only three hours' flying time away, easily accessible from many European markets. Scotland's core product, the weekend leisure break, is under threat as more and more destinations compete for the same markets. Scotland cannot stand still, because if it does complacency will lead to the Yesterday's Destination scenario. The margin of error between the Weekend Getaway and Yesterday's Destination is only 3.4 per cent per annum, because competition will be fierce over the next five years as consumers want more for less. Quality is no longer a distinguishing factor but a hygiene factor. This means maintaining and investing in quality just to keep up with the competition. If this is not done, Scotland will become Yesterday's Destination.

Scotland should be both physically and emotionally accessible to its markets. Physical access is all about a three-hour journey time for rail, air, road and sea links. As transport is caught in disinflation, access for the consumer has to be a low-cost model. Scotland has to be emotionally accessible to the consumer in terms of values, experiences and recall of images. As the population get older and wiser, they tend to mistrust or not believe official pronouncements or information. They disregard direct marketing campaigns, preferring websites and guides such as 'Lonely Planet', or they turn to their friends ${ }^{48}$ for advice. In these situations, appealing to the consumer's subconscious in an indirect manner is more effective. It is about promoting the destinations as long-term enduring images rather than a short-term strategy. If these factors are not adhered to, Scotland will become Yesterday's Destination.

The consumer is changing. The tourist has more disposable income as a result of relatively stable employment, low interest rates, low inflation and more home ownership. They spend more money on themselves, have a desire to travel to faraway places and think nothing of taking a weekend break. They also want their money to go further, so they will spend less on transport and accommodation. The consumer is more aware of circumstances and is more complex. Destination image, safety, accessibility, wars in other countries, economic environment, exchange rates and the weather have all driven Scottish tourism's success in 2003. Changes in any of these circumstances or drivers will affect Scottish tourism. The key to success is maximising the potential and opportunity in whichever scenario unfolds; whether this is in developing resorts for international tourism in Exclusive Scot- 
land or family-centred holidays in Yesterday's Destination. Tourism in Scotland will always be here, but VisitScotland's responsibility is to guide and deliver an appropriate strategy, whatever the scenario. Such a strategy will depend upon short-term tactical decisions and long-term strategic decisions.

The short-term decisions are about optimising the present trends without spoiling the product. For example, the growth in city tourism can be combined with rural pursuits. Hub tourism is where the tourist will stay in city locations but adventure out of the city boundaries to try white-water rafting or play golf. Investment in e-commerce as a gateway is essential: for example, myscotland.com/ visitscotland.com must have a high internet optimisation value to succeed in a competitive environment. General awareness of Scotland as a high-quality environment is well established and this, combined with a focused segmented product portfolio that maximises the opportunity, is essential. For example, the importance of well-being is already well established as a retail product. Outlets like Arran Aromatics will replace traditional tourism souvenir outlets as weekend visitors are more concerned about purpose, value and usefulness rather tourism novelty.

Over the next ten years one is going to see growth coming from European markets rather than the USA, due to the expansion of the EU, close proximity and direct links. The American market, although it will still be substantial, suffers from shocks such as exchange rates and terrorism. Europe will be the largest geographical market for Scotland's international tourists by 2015 . Within the UK, as transport links improve, further growth will come from London and the south-east of England, which has a growing population density compared to other parts of the UK.

Long-term decisions and strategy must concentrate on creating a strategic conversation about tourism in which the value and intellectual power of tourism are realised. It is this appreciation of tourism, on which the nation and economy depend, that will be the key stepping-stone from where Scotland is now to a Dynamic Scotland scenario. If that strategic argument can be won, success will lead to the private sector investing substantial amounts in destination development. Big players such as Marriott Resorts and Holiday Inn only invest in destinations where success has been proven and where international tourists want to visit. Such an ambition means that Scotland becomes an international long-haul tourism destination which tourists have aspirations to visit. Scotland is their dream destination.

But if Scotland wants to achieve that dream it needs to start with a vision, where tourism is Scotland's first and everlasting industry.

\section{SCOTLAND'S FIRST AND EVERLASTING INDUSTRY}

Tourism will be the first industry of Scotland and the first reason to live, play and work in Scotland. Tourism in Scotland will be a firstclass experience and Scotland will be a firstchoice destination. A Dynamic Scotland scenario will probably not be deliverable until beyond 2015, but Scottish tourism has a responsibility to ensure that the steppingstones are put in place in order to achieve that scenario. This means it has an obligation to realise its full potential and maximise opportunities in order to sustain an everlasting industry up to and beyond 2015. This responsibility means developing a tourism economy which will ensure an everlasting industry for generations to come. Those who have responsibility for tourism today are the guardians of that everlasting future. Tourism will be Scotland's first and everlasting industry.

\section{REFERENCES}

(1) NVision (2002) 'The Future of the UK Holiday and Tourism Industry', Future Foundation, London.

(2) Ibid.

(3) World Tourism Organisation (2003) 'Leading the world's largest industry', www. world-tourism.org/frameset/frame_ 
aboutwto.htm.

(4) BBC (2002) 'UK travel sector still suffering', http://news.bbc.co.uk/1/hi/business/ 1754745.stm.

(5) BBC (2003) 'SARS hits Hong Kong growth', http://news.bbc.co.uk/1/hi/ business/2934867.stm\#startcontent.

(6) OEF (2003) 'Economic Impact of War on Scottish Tourism', VisitScotland, Edinburgh.

(7) Schweimler, D. (2001) 'Hurricane Michelle: Assessing the damage', http://news. bbc.co.uk/1/hi/world/from_our_own_ correspondent/1647808.stm.

(8) VisitScotland (2003) 'Trends affecting tourism - The changing consumer', www. scotexchange.net/KnowYourMarket/ tourism-trends-consumerhealth.asp.

(9) WWF (2001) 'Tourism and climate change', Worldwide Fund for Nature, London, www.wwf.org.uk/filelibrary/pdf/ tourism_and_climate_change.pdf.

(10) Scottish Executive (2001) 'A new strategy for Scottish tourism', www.scotland. gov.uk/library2/doc11/sfst-04.asp.

(11) Hay, B. (2002) 'A vision of tourism in 2020', in Hood, N., Peat, J., Peters, E. and Young, S. (eds) 'Scotland in a Global Economy: The 2020 Vision', Palgrave, Basingstoke

(12) Durie, A. (2003) 'Scotland for the Holidays. Tourism in Scotland c1780-1939', Tuckwell Press, East Linton.

(13) Crown Office (2002) 'Tourism Framework for Action', Stationery Office, Edinburgh.

(14) Enterprise and Lifelong Learning Committee (2003) 'Report on the Future of Tourism in Scotland', Scottish Parliamentary Corporate Body, Stationery Office, Edinburgh.

(15) Garrod, B., Fyall, A. and Leask, A. (2002) 'Scottish visitor attractions: Managing visitor impacts', Tourism Management, Vol. 23, No. 3, pp. 265-279.

(16) Prentice, R. and Andersen, V. (2003) 'Festival as creative destination', Annals of Tourism Research, Vol. 30, No. 1, pp. 7-30.

(17) Hay, B. and Buchanan, P. (2003) 'Trends in Scottish Tourism, 1993-2003', VisitScotland, Edinburgh.

(18) Packman, C. (2002) 'Business Tourism Review', VisitScotland, Edinburgh.

(19) Seaton, A. V. (1998) 'The history of tourism in Scotland: Approaches, sources and issues', in McLellan, R. and Smith, R. (eds)
'Tourism in Scotland', Thomson Business Press, London.

(20) OEF, ref. 6 above.

(21) Scottish Executive (2002) '30 year vision for air transport', www.scotland.gov.uk/ pages/news/2002/07/SEET082.aspx.

(22) VisitScotland (2003) 'Know your market', www.scotexchange.net/KnowYourMarket/kym-activityhols.htm.

(23) MacLellan, R. (2003) 'Tourism and the Scottish environment', in MacLellan, R. and Smith, R. (eds) 'Tourism in Scotland', Thomson Business Press, London.

(24) Hall, C. (2002) 'Travel safety, terrorism and the media. The significance of the issueattention cycle', Current Issues in Tourism, Vol. 5, No. 5, pp. 458-466.

(25) Hay, ref. 11 above.

(26) NVision, ref. 1 above.

(27) Yeoman, I. and Packman, C. (2003) Interview with Mike Cantley, Vice Chairman, VisitScotland, January.

(28) Seaton, A. V. (2002) 'Imagining Scotland: Tradition, representation and promotion in Scottish tourism since 1750', Tourism Management, Vol. 19, No. 3, pp. 303-304.

(29) Seaton, A. V. and Hay, B. (1998) 'The marketing of Scotland as a tourism destination, 1985-1996', in McLellan, R. and Smith, R. (eds) 'Tourism in Scotland', Thomson Business Press, London.

(30) Barlett, T. (2002) 'World Overview and Tourism Topics 2002', World Tourism Organisation, Madrid.

(31) Kerr, B., Barron, G. and Wood, R. (2001) 'Politics, policy and regional tourism administration: A case examination of Scottish area tourist board funding', Tourism Management, Vol. 22, No. 6, pp. 649-657.

(32) Kerr, B. and Wood, R. C. (2000) 'Political values of tourism and hospitality industry professionals: A Scottish case study', Tourism Management, Vol. 21, No. 4, pp. 323-330.

(33) BBC (2002) 'Stop talking Scotland down', http://news.bbc.co.uk/1/hi/scotland/ 2248012.stm.

(34) Prentice and Andersen, ref. 15 above.

(35) Prideaux, B. (2000) 'The role of the transport system in destination development A general model', Tourism Management, Vol. 21, No. 1, pp. 53-63.

(36) BBC (2003) 'Tourist trade looks to unemployed', http://news.bbc.co.uk/1/hi/ scotland/2834725.stm.

(37) Findlay, A. (2002) 'Analysis: Scotland's 
Census figures', http://news.bbc.co.uk/1/ hi/scotland/2288292.stm.

(38) BBC (2003) 'Scots economy shows slight growth', http://news.bbc.co.uk/1/hi/ scotland/2728375.stm.

(39) BBC (2002) 'Analysts fear threat of ever lower prices', http://news.bbc.co.uk/1/hi/ business/2356435.stm.

(40) Hooper, P. (2002) 'Marketing London in a difficult climate', Journal of Vacation Marketing. Vol. 9, No. 1, pp. 81-88.

(41) Harrison, S. J., Winterbottom, S. J. and Sheppard, C. (1999) 'The potential effects of climate change on the Scottish tourist industry', Tourism Management, Vol. 20, No. 2, pp. 203-211.

(42) Font, X. (2002) 'Environmental certification in tourism and hospitality: Progress, process and prospects', Tourism Management, Vol. 23, No. 3, pp. 197-205.

(43) Ashcroft, B. (2000) 'A perspective on Scot- tish manufacturing. Manufacturing 2020', Royal Society of Edinburgh Foresight Seminar Series, 23rd February.

(44) Heijden, K., Bradfield, R., Burt, G., Cairns, G. and Wright, G. (2002) 'The Sixth Sense: Accelerated Organizational Learning With Scenarios', John Wiley \& Sons, Chichester.

(45) Woulde, D., Damgaard, G., Hegge, M., Soholt, D. and Bunkers, S. (2003) 'The unfolding; Scenario planning in nursing', Nursing Science Quarterly, Vol. 16, No. 1, pp. 27-35.

(46) De Greus, A. (1988) 'Planning as learning', Harvard Business Review. Vol. 66, No. 2, pp. 70-74.

(47) Schmenner, R. (1995) 'Service Operations Management', Prentice Hall, New Jersey.

(48) Silverstein, M. and Fiske, N. (2003) 'Trading Up: The New American Luxury', Portfolio, New York. 